\title{
ON THE CONSTITUTIONALITY OF SINGLE-MEDIUM PUBLIC SCHOOLS
}

\author{
BRAHM FLEISCH* \\ STUART WOOLMAN**
}

\begin{abstract}
The Constitution of the Republic of South Africa, 1996 allows the creation of independent educational institutions and permits such institutions to enforce admissions policies that discriminate between learners who wish to participate in the affairs of a given linguistic and cultural community and those who do not wish to participate in or advance that community's vision of the good life. When it comes to public schools, however, the state's tolerance for discriminatory language policies of any kind is extremely limited and rightly inclines in favour of the language preferences of learners from historically disadvantaged communities. A proper reading of s 29(2) of the Constitution supports the following propositions. First, all learners have the right - where practicable - to receive an education in their preferred language of instruction. Second, where a sizeable cohort of learners does not have ready access to a public school that offers them adequate instruction in their preferred medium of instruction, neither the School Governing Body nor the principal of a single-medium school can exclude such a cohort of learners by means of an admissions policy that seeks to privilege a particular language. Third, although s 29(2) recognises that singlemedium schools are an acceptable form of public school, the Constitution's commitment to equity and historical redress means that the right of all learners to a basic education in their preferred language of instruction at public schools will generally trump any individual school's pre-existing preference for linguistic homogeneity. Only where sufficient resources exist to ensure that the cohort of South African learners in question will receive an adequate, and for all intents equal, education in their preferred language of instruction at another public school will the state be obliged to accommodate a single-medium school's desire to remain linguistically homogeneous.
\end{abstract}

\section{INTRODUCTION}

Conflict around the issue of language informs almost every stage of this Republic's history. ${ }^{1}$ According to Giliomee, the language issue began to smolder in the ashes of the South African War when Britain introduced

\footnotetext{
* Associate Professor, School of Education, University of the Witwatersrand, Johannesburg.

** Senior Lecturer in Law and Research Associate, Centre for Human Rights, University of Pretoria; Research Associate, South African Institute for Advanced Constitutional, Human Rights, Public and International Law (SAIFAC). We are very grateful to the SAJHR referees for their helpful comments on an earlier draft of this article.

1 For the general contours of this history, see LM Thompson A History of South Africa (2001); W Beinart Twentieth Century South Africa (2001). For an understanding of the links between culture, language and racism, see S Dubow Scientific Racism in Modern South Africa (1995).
} 
English as the sole official language in the ex-republics. While the principle of linguistic equality between English and Dutch was enshrined in the Union Constitution, the prevailing assumption amongst English speakers was that English would, ultimately, prevail. Indeed, in the 1920s, big business and the civil service were dominated by English speakers. While new appointments to the civil service were required to be bilingual, Afrikaners were vastly underrepresented: few Afrikaner children finished the seventh year of school required for state employment. $^{2}$

The political pressure for single-medium education breached the surface during the rise of Afrikaner nationalism in the late 1920s and early 1930s. The demands began when the Dutch Reformed Church made the connection between white poverty and education, and raised in particular the failure of poor Afrikaner children to master the dual mediums of instruction (English and Dutch). The Church and other organs of civil society placed increasing pressure on provincial governments to make Afrikaans, rather than Dutch, the medium of instruction for Afrikaans-speaking children. At the same time as they sought to supplant Dutch with Afrikaans, they pressed for single-medium Afrikaans-speaking institutions. Between 1932 and 1958, single-medium Afrikaans schools rose, as a proportion of all white schools, from 28 percent to 62 per cent. ${ }^{3}$ Over time, Afrikaner nationalist teachers, committed to a very particular cultural, linguistic, religious and political project, came to form the core of single-medium Afrikaans school staffs.

Prior to the Second World War, South Africa possessed a complex network of language practices and an equally complex arrangement of single-medium, dual-medium and parallel-medium institutions. ${ }^{4}$ This surface complexity masked the increasingly strong shift, amongst the Afrikaner majority, towards a preference for the 'purity' of singlemedium schools. After the outbreak of the Second World War, the 'gloves' on education policy came off. ${ }^{5}$ The United Party articulated a vision of a unified white South Africa that could be achieved through a policy of compulsory bilingual education. The National Party hit the stumps on a campaign that emphasised a comprehensive and exclusive vision of Afrikaner cultural, linguistic, religious and political life. For the

2 H Giliomee 'The Rise and Possible Demise of Afrikaans as Public Language' (2004) 10 Nationalism \& Ethnic Politics 25.

3 See EG Malherbe Education in South Africa Vol 2 (1977).

4 The diversity of language medium types and the various effects of these language practices was the pretext for EG Malherbe's famous study The Bilingual School: A Study of Bilingualism in South Africa (1946).

5 For an account of the conflict over bilingual schooling see B Fleisch 'Social Scientists as Policy Makers: EG Malherbe and the National Bureau for Social and Educational Research, 19291943' (1995) 21 J of Southern African Studies 349. 
National Party, however, this ostensibly 'authentic' vision was primarily a vehicle for achieving political hegemony. As EG Malherbe observes:

The United Party maintained that in a bilingual country like South Africa it was wrong to segregate Afrikaans and English-speaking children living in the same community. By keeping the children together in the same school they would learn to appreciate each other as persons by playing on the same school teams, and thus lay the foundation for a common loyalty as South Africans... Against this the National Party contended that bilingualism was not the aim of education ... [T] he nationalists had no scruples about artificially segregating Afrikaans-speaking children in order to foster exclusive Afrikaner nationalism ... Both parties wanted to use the education system to achieve their political ends — the one to unite, the other to divide. ${ }^{6}$

Despite the fact that both political parties clearly understood that language policy was a powerful mechanism for galvanising their political bases and an effective instrument for social engineering, one essential difference between the two parties remained. The National Party, and Afrikaner nationalists generally, experienced a recurring anxiety that 'one culture would be swamped by the other." 7 The National Party exploited this anxiety - and the related fantasy that single-medium public schools would eliminate the source of the anxiety - to win the 1948 elections.

Apartheid ushered in a new set of linguistic, cultural and political imperatives. No objective was more important, perhaps, than the use of the state machinery to privilege Afrikaans in Afrikaner communities and to place Afrikaans on an equal footing with its historical rival, English.

The logic of apartheid led, almost inexorably, to the 'Eiselen' Commission Report on Native Education. ${ }^{8}$ The Eiselen Report made a strong case for compulsory African language instruction for African students up to and during high school. While facially consistent with UNESCO's best linguistic practices, the policy was opposed by missionaries and local African 'pro-English' elites. The National Party presupposed that African 'language' communities had a vision of themselves similar to the comprehensive vision of the good life offered

6 Malherbe (note 3 above) 39.

7 While originally articulated in the 1930s, the theme has retained its currency. Rassie Malherbe has expressed this anxiety as follows: 'Although in principle, dual and parallel medium institutions of instruction may, under suitable circumstances, be the appropriate option to fulfill the right to education in one's preferred language, it has the shortcoming that diminishing numbers of a particular language group puts tremendous pressure on that language and may in practice lead to an institution eventually becoming single-medium. ... [I]n parallel and dual medium schools the English component is numerically becoming progressively larger and that in relation, the other language component of such schools is becoming smaller and marginalised. Many parallel medium schools will eventually become completely English medium.' R Malherbe 'Submission to President Nelson Mandela on Behalf of a Group of Afrikaans Organizations' (15 May 1996).

8 Republic of South Africa Report of the Commission on Native Education: Chair: WNN Eiselen (1951). See also LE Meyer 'A Report on South Africa's Black Universities' 4(3) Issue: A Journal of Opinion of the African Studies Association 12. 
by the Afrikaner, Christian, nationalist community. ${ }^{9}$ The foundation for such a community of true believers and politicians alike was (and perhaps remains) the 'single language school'.

To impose this vision of the good life and its requirement of singlemedium schools upon a largely resistant populace required social engineering on an unprecedented scale. ${ }^{10}$ Despite the logistical and political hurdles, the National Party had, by the 1970s, achieved its aim. Most primary school learners were initially educated in their mother tongue. Few children were schooled in the 'wrong' language. Although African learners switched to English, and in some instances Afrikaans, at the end of primary school, these learners were still confined, as far as possible, to ethnic schools in the townships and the homelands. ${ }^{11}$

In 1976, apartheid in education began to fall apart. The resistance did not flow from the rejection of single-medium schooling. What African learners rejected was the imposition of both English and Afrikaans. The engineers of apartheid and Christian National education had overplayed their hand. ${ }^{12}$

And yet the belief that single-medium schooling would serve as the glue that bound the unique linguistic, cultural and religious features of the Afrikaner people together remained very much alive. It even survived the Multi-Party Negotiating Forum ('MPNF') at Kempton Park. The interim Constitution, in $\mathrm{s} 32$, continued to allow communities 'to establish, where practicable, educational institutions based on a common culture, language or religion, provided that there shall be no discrimination on the ground of race. ${ }^{13}$ Negotiations in the Constitutional

9 For a fuller account of the issues of language in Bantu Education, particularly the work of WNN Eiselen as one of the key architects of apartheid, see C Kros Economic, Political and Intellectual Origins of Bantu Education, 1926-1951 (1996) (unpublished PhD dissertation, University of the Witwatersrand).

10 See M Horrell A Decade of Bantu Education (1964); P Kallaway (ed) Apartheid and Education (1984). See also K Hartshorne Crisis and Challenge: Black Education 1910-1990 (1992) 186217; J Hyslop The Classroom Struggle; Policy and Resistance in South Africa: 1940-1990 (1999).

11 See Hartshorne (note 10 above) 203-207.

12 For a contemporary account, see J Kane-Berman Soweto: Black Revolt, White Reaction (1979). See also C MacDonald Crossing the Threshold to Standard 3 (1991). Macdonald notes that within African schools, from 1977 onward, the debate shifted away from Afrikaans as a medium of instruction, and focused on English as the medium of instruction. By the mid 1980s, most schools in the Department of Education and Training used mother-tongue instruction up until the end of Standard 2 (now Grade 4) and then switched to English as a medium of instruction. This practice became the focus of the HSRC Threshold Project in the late 1980s. This project identified the source of the high failure rate and subsequent drop-out problem as the abrupt shift from mother-tongue to English between Standards 2 and 3. Initially in some homelands, and then later on in some township schools in the 1990s, this shift to English started earlier and earlier. As one of our anonymous referees points out, within Afrikanerdom, the period was marked by a shift, in some quarters, from using the state as a means for preserving cultural identify to a set of policies that linked the community's survival to a new, and not necessarily, conducive discourse of minority rights.

13 Constitution of the Republic of South Africa, Act 200 of 1993 ('interim Constitution' or 'IC'). 
Assembly around the issue of single-medium schools under the Final Constitution were even more protracted and led to a deadlock between the African National Congress (ANC) and the National Party (NP). ${ }^{14}$ The ANC, which viewed single-medium Afrikaans schools as vehicles for continued racial exclusion and the perpetuation of minority privilege, refused to sanction any reference to single-medium schools in the Final Constitution. ${ }^{15}$ The NP, which viewed single-medium schools as the last vestige of public power in the new dispensation, repeatedly pushed for their inclusion. The ANC, though assured of the passage of a national referendum on its version of the Final Constitution should constitutional negotiations fail, believed that the good will derived from some compromise on this issue, and a Final Constitution supported by all the major parties, outweighed the benefits to be secured from an outright victory on this issue. The NP knew that it could not win either in the Constitutional Assembly or at the polls. It therefore engaged in the kind of political brinkmanship that would satisfy its constituents, but ultimately capitulated when the ANC agreed to make some mention of single-medium schools in the Final Constitution. Here then is the result of that compromise in the Constitution at s 29(2):

Everyone has the right to receive education in the official language or languages of their choice in public educational institutions where that education is reasonably practicable. In order to ensure the effective access to, and implementation of, this right, the state must consider all reasonable educational alternatives, including single-medium institutions, taking into account - (a) equity; (b) practicability; and (c) the need to redress the results of past racially discriminatory laws and practices. ${ }^{16}$

Does this passage secure - as some authors argue - continued state support for all single-medium public schools, and, in particular, singlemedium Afrikaans public schools? Or does it — as other authors contend

14 On the history of the negotiations for the interim Constitution, see LM Du Plessis 'A Background to Drafting the Chapter on Fundamental Rights' in B de Villiers (ed) Birth of a Constitution (1994) 89; H Corder 'Towards a South African Constitution' (1994) 57 Modern LR 491; H Corder \& L Du Plessis Understanding South Africa's Transitional Bill of Rights (1995); G Heald Learning Amongst Enemies: A Phenomenological Study of the South African Constitution Negotiations from 1985 to 1998 (2007) (unpublished PhD thesis, University of the Witwatersrand). On the history of the negotiations for the Final Constitution, see I Currie \& $\mathbf{J}$ De Waal The Bill of Rights Handbook (2005) 1, 23; G Heald Learning Amongst Enemies (supra); S Woolman, H Klug \& R Biabuch 'Constitutional History' in S Woolman et al (eds) Constitutional Law of South Africa 2ed (2007) chapter 2.

15 Then ANC spokesperson on education, Blade Nzimande wrote: 'The issue of single-medium institutions is a mere red herring. What the NP wants the constitution to guarantee is the right to have exclusive white Afrikaner schools, not single-medium institutions.' B Nzimande 'Address to the Constitutional Assembly - 7 May 1996', available at < http:// www.polity.co.za>. Evidence to support this supposition has emerged in recent work on school financing. Motala has recently shown that Afrikaans single-medium schools continue to be financially advantaged in terms of state expenditure even after the end of apartheid. S Motala Education Transformation in South Africa: Finance Equity Reform in Schooling after 1998 (unpublished PhD thesis, University of the Witwatersrand).

16 Constitution of the Republic of South Africa, 1996. 
- eliminate any express entitlement for single-medium public schools except where such schools offer redress for communities whose mother tongues were repressed under English and Afrikaner rule? Section 29(2) does not support either of these two readings, but rather raises the question of the extent to which the particularist demands of linguistic, cultural and religious communities with comprehensive visions of the good life can be accommodated in our public schools. ${ }^{17}$ Section 29(2) also draws our attention, in the form of its sister clause s 29(3), to the space that the Constitution creates for the expression of the particularist claims of linguistic, cultural and religious communities and the ability of those claims to be (better) accommodated in independent schools. ${ }^{18}$

There exists, after twelve years of constitutional jurisprudence, a sizable body of case law that engages issues of language, culture and religion and their place in public schools and in independent schools. The primary driver of this body of education litigation is the State's and the Afrikaans-speaking community's concern about the continued existence of single-medium Afrikaans public schools. Put differently, both the state and the Afrikaans-speaking community want to know the extent to which the Constitution vouchsafes the right of school governing bodies to determine and to retain their language policies in the face of opposition from provincial government and/or small groups of learners and their parents who wish to change the language policies in these institutions.

This article attempts to answer the following question: Does South Africa's legal regime guarantee existing public, single-medium, Afrikaans institutions the right to retain their language policies?

Part II of this article grounds the answer to that question in a particular reading of the history and the language of those constitutional provisions designed to promote and to protect religious, linguistic and cultural communities. This reading demonstrates that our liberal democratic order affords religious, linguistic and cultural communities significant latitude when it comes to the establishment and the maintenance of private or independent schools designed to further particular comprehensive visions of the good life and offers such communities far less solace when it come to the establishment and the maintenance of single-medium public schools.

Part III takes a far more hard-nosed view of the law that governs admissions policies and language policies in public schools. After

17 For more on the history of Afrikaans as a medium of instruction in our public schools, see $\mathrm{P}$ Plüddemann, D Braam, M October \& Z Wababa 'Dual-medium and Parallel-medium Schooling in the Western Cape: From Default to Design' PRAESA - Occasional Papers No 17 (2004); W Visser 'Coming to Terms with the Past and the Present: Afrikaner Experience of and Reaction to the "New" South Africa' (Seminar at The Centre of African Studies, University Of Copenhagen (30 September 2004)).

18 S Woolman 'Defending Discrimination: On the Constitutionality of Independent Schools that Promote a Particular, If Not Comprehensive, Vision of the Good Life' (2007) 22 Stellenbosch LR 39 . 
mapping the most critical bodies of law - the Constitution, the South African Schools Act ('the Schools Act'), the Promotion of Equality and Prevention of Unfair Discrimination Act ('PEPUDA') and our courts' nascent jurisprudence - onto the admissions policies and language policies of public schools, we come to the following conclusions. First, some real constitutional space remains for single-medium, public schools and, therefore, for single-medium, Afrikaans public schools. Second, the constitutional and statutory entitlement to such schools - under current historical conditions - is relatively weak. A recent line of cases in the High Court and the Supreme Court of Appeal suggest that 'language and culture' will not so readily be permitted to determine the admissions policies of a public school and that single-medium Afrikaans schools are fighting a rear-guard, and potentially losing, battle with the state over transformation. ${ }^{19}$ Third, the result of this legal analysis is that communities which wish to preserve their linguistic, cultural and religious ways of being in the world will find themselves on much more solid legal ground when they create independent schools - in terms of s 29(3) designed to further their comprehensive visions of the good life. Afrikaans-speaking communities, like any other linguistic, cultural or religious community, have no special status in our liberal democratic order and must be able to create independent schools if they wish to be assured of retaining their cultural and linguistic integrity.

\section{A Brief Constitutional History of Religious, Linguistic \& Cultural Rights}

In this section we examine the drafting history of the interim Constitution and the 1996 Constitution and some of the jurisprudence generated during the brief period between these two founding documents. This history goes some distance towards explaining why political group rights and rights to public institutions such as single-medium, Afrikaans, primary and secondary schools were never enshrined in our basic law.

For starters, before the velvet revolution of 1994, most political claims based on culture, language, ethnicity and religion were greeted with suspicion, and, sometimes, outright hostility by the majority of South

19 This battle is not only being lost in the courts. Students themselves are choosing English medium (or at least parallel medium, public) schools over single-medium, Afrikaans, public schools. Given that each secondary school draws on one or two primary schools, the fact that there are approximately 300 single-medium Afrikaans secondary schools means that the number of single-medium Afrikaans schools (primary, secondary and combined) falls somewhere between 600 and 850 . Even the higher figure means that single-medium Afrikaans public schools constitute only 2 per cent of the estimated 30000 public schools in the country. A colourable claim can be made that such a low figure warrants some degree of judicial solicitude. On the other hand, no number, large or small, can be used to justify overt discrimination or radical inequity in the distribution of such an important public good as education. 
Africans. ${ }^{20}$ From the passive resistance of Ghandi, through worker movements of the early 20th century to the Freedom Charter, the preferred language of liberation was that of human rights discourse. The liberation movement's utilisation of rights discourse reflected a considered rhetorical response to romantic assertions of white, Christian, English and Afrikaner supremacy.

The ANC's universalist orientation provides a partial explanation for the failure of most group-based claims during CODESA and the MPNF. The ANC rejected every attempt to entrench what it termed 'racial group rights'. ${ }^{21}$ For Afrikaner nationalists, political power would have to be traded for a negotiated settlement. That peace, and the retention of economic privilege by the white minority, would be vouchsafed by a firm ANC commitment to a justiciable Bill of Rights. ${ }^{22}$

20 See A Sachs 'Opening Remarks' KAS Multiculturalism Seminar (1999) $1<w w w . k a s . o r g . z a /$ Publications/SeminarReports/Multiculturalism/SACHS1.pdf $>$; H Giliomee 'The Majority, Minorities and Ex-nationalities in South Africa and the Proposed Cultural Commission' KAS Multiculturalism Seminar (1999) 37, <www.kas.org.za/Publications/Seminar Reports/Multiculturalism/GILIOMEE>.

21 See S Woolman 'Community Rights: Religion, Language and Culture' in S Woolman et al (eds) Constitutional Law of South Africa 2ed (2007) chap 58; S Woolman \& J Soweto-Aullo 'Commission for the Promotion and the Protection of the Rights of Religious, Linguistic and Cultural Communities' in Woolman et al (eds) chap 24F.

22 The problem of accommodating, and protecting, ethnic, religious and linguistic communities in a democratic state dominated the political debates and the lengthy constitutional negotiations that preceded the enactment of the Interim Constitution. Between 1986 and 1991, the South Africa Law Commission investigated various mechanisms for the protection of group rights. See South Africa Law Commission Group and Human Rights, Working Paper 25, Project 58 (1989). To this end, it solicited submissions from white right-wing intellectuals on the right of minorities to seek recognition as distinct societies and to resist assimilation into a common national culture. See South Africa Law Commission Group and Human Rights, Interim Report (1991). Notwithstanding the contentiousness of white minority concerns, the language and cultural rights provision of the Interim Constitution's Bill of Rights secured virtually universal consent from Multi-Party Negotiating Forum participants. See LM Du Plessis 'A Background to Drafting the Chapter on Fundamental Rights' in B de Villiers (ed) Birth of a Constitution (1994) 89, 93. Section 31 of the interim Constitution attracted near universal assent because, though it echoed art 27 of the International Covenant on Civil and Political Rights, it avoided art 27's protection of discrete sets of rights-holders. Both the ANC and the NP eschewed more substantial minority rights protection.

However, community rights were not entirely anathema to the ANC or to the NP. The NP believed that white minority interests would be better protected at the level of distribution of governmental power, rather than by judicial mechanisms. The National Party proposed only non-discrimination guarantees and individual rights to speak a language or to participate in 'cultural life'. See Government of the Republic of South Africa Proposals on a Charter of Fundamental Rights (2 February 1993) arts 6 and 34. We have already noted the degree to which the ANC was ill-disposed towards recognition of community, minority, collective or group rights. The most the ANC would concede were rights to form 'cultural bodies', to religious freedom, and, perhaps, to require that the state act positively to further the development of the eleven South African languages to be treated as official languages. See African National Congress A Bill of Rights for a New South Africa: Preliminary Revised Version (1992) arts 5(3)-5(7). The ANC insisted that minority rights qua static, nondemographically representative levels of political representation were unacceptable. The Bill of Rights largely reflects the ANC's compromise between unfettered majority rule on the one hand, and structural guarantees for privileged, but now 'vulnerable', political minorities. 
However, the rejection of group political rights in both interim and 1996 Constitutions was at least partially compensated by the 'notable levels of constitutional significance' to which cultural, linguistic and religious matters were elevated. The 1996 Constitution contains six different provisions concerned with culture, eight with language and four with religion. ${ }^{23}$ The Constitution, as a liberal political document, carves out the 'private' space within which self-supporting cultural, linguistic and religious formations might flourish. ${ }^{24}$

Kriegler $\mathbf{J}$, in the Gauteng School Education Bill decision, offers a succinct account of the basis for and the extent of the basic law's protection of this private space in the educational domain. ${ }^{25}$ Section 32 (c) (the predecessor of s 29(3) of the 1996 Constitution) and then extant national and provincial education legislation and subordinate legislation constitute:

a bulwark against the swamping of any minority's common culture, language or religion. For as long as a minority actually guards its common heritage, for so long will it be its inalienable right to establish educational institutions for the preservation of its culture, language or religion .... There are, however, two important qualifications. Firstly, ... there must be no discrimination on the ground of race. .... A common culture, language or religion having racism as an essential element has no constitutional claim to the establishment of separate educational institutions. The Constitution protects diversity, not racial discrimination. Secondly, ... [the Constitution] ... keeps the door open for those for whom the State's educational institutions are considered inadequate as far as common culture, language or religion is concerned. They are at liberty harmoniously to preserve the heritage of their fathers for their children. But there is a price, namely that such a population group will have to dig into its own pocket. ${ }^{26}$

23 Provisions of the 1996 Constitution dealing with culture, language and religion include, but are not limited to: (a) ss 9, 30, 31, 235 (culture); (b) ss 6, 29, 30, 31, 35, 235 (language); and (c) ss $9,15,30,31$ (religion).

24 We can offer a three-fold, and relatively uncontroversial, explanation of the Constitution's protection of such private space. First, every liberal democratic constitution is committed to zones of privacy, autonomy, self-governance and self-actualization that lie somewhere beyond the reach of the state. Second, the fragility of the new South African government married to a deeply religious South African citizenry obliged the government to cede authority over the manner in which 'private' or 'independent' schools were permitted to serve rather narrow sectarian interests - even where the state could predict that privileged communities would use religion as a proxy for class so as to re-inscribe existing patterns of privilege. Third, the long history of school autonomy produced a reality, on the ground, that was simply impossible to ignore. The politically expedient motivations behind Afrikaner nationalism had ultimately created a genuine community - with a particular religious, cultural and linguistic vision of the good life - that sought to further the ends of the community through single-medium schools. The extent to which the Constitution protects 'public' space and provides 'public' goods in the service of particularist ends is the question as issue. Liberal constitutional theory, with its dual commitments to 'equality of respect' (individual dignity) and 'equality of recognition' (pluralism), is invariably at odds with itself over claims made on state resources for the particular ends of a specific cultural, linguistic or religious community. See $\mathrm{S}$ Woolman 'Community Rights' (note 21 above) chap 58.

25 Ex parte Gauteng Provincial Legislature: In re Dispute Concerning the Constitutionality of Certain Provisions of the Gauteng School Education Bill of 19951996 (3) SA 165 (CC) ('Gauteng School Education Bill').

26 Ibid paras 39-42. 
Kriegler $\mathbf{J}$ offers no comment on, and certainly no support for, the contention that communities bound by common culture, language or religion have some entitlement to state support. Quite the opposite. While sympathetic to the belief that communities bound by common culture, language or religion are an important source of meaning for many South Africans, Kriegler $\mathbf{J}$ seems to suggest that the post-apartheid state will no longer support public institutions that privilege one way of being in the world over another.

But the truth about the existence of continued public support within public institutions for particularistic, comprehensive visions of the good life in our post-apartheid constitutional order is more complex and nuanced than one quote from a single judgment allows. Here, the Constitutional Court's jurisprudence is sufficiently developed to provide useful guidance as to how the state ought to engage the religious, cultural and linguistic communities that constitute the society and how those communities ought to engage one another.

For example, in Minister of Home Affairs v Fourie, the Constitutional Court found that the state could not continue to enforce common-law rules and statutory provisions that prevented same-sex life partners from entering civilly-sanctioned marriages and that denied same-sex life partners the status, the responsibilities and the duties enjoyed by opposite-sex life partners. ${ }^{27}$ State sponsored discrimination would not be tolerated. The Fourie Court did not make the same demands of religious denominations or religious officials. It held that the Constitution had nothing to say about religious prohibitions on gay and lesbian marriage and could not be read to require religious officials to consecrate a marriage between members of a same-sex life partnership. So long as religious communities do not distribute public goods - or are not the sole distributors of such goods - the state, on the Fourie Court's account, cannot justifiably coerce a religious community into altering its basic beliefs and practices. ${ }^{28}$ But therein lies the rub for advocates of single-medium public schools. Public schools are public, not private entities, and the state has an overriding obligation to ensure equal treatment of all of its citizens by all of its state officials (including teachers and principals.) Single-medium public schools that engage in exclusive and discriminatory linguistic admissions practices would appear to constitute, on their face, a departure from the constitutional norms of equality and dignity. ${ }^{29}$

27 Minister of Home Affairs v Fourie 2006 (1) SA 524 (CC) ('Fourie'); See also Fourie v Minister of Home Affairs 2005 (3) SA 429 (SCA).

28 Fourie (CC) (ibid) paras 90-96.

29 See S Woolman 'Dignity' in S Woolman et al (eds) Constitutional Law of South Africa 2ed (2005) chap 36; N Haysom 'Dignity' in H Cheadle, D Davis \& N Haysom (eds) South African Constitutional Law: The Bill of Rights (2002) 123. 
Is there space within our liberal constitutional framework for public institutions that service the (exclusive and discriminatory) ends of religious, cultural and linguistic communities with relatively comprehensive visions of the good life? A significant number of constitutional structures and justiciable rights in the Constitution, as well as the Constitutional Court's gloss on the basic law, support the proposition that such space exists.

For example, the Commission for the Promotion and the Protection of the Rights of Cultural, Religious and Linguistic Communities ('CRLC') does not merely regulate disputes between the state and various communities or resolve conflicts between communities themselves. The CRLC is charged with the active promotion of such communities though the creation of cultural councils. Moreover, it possesses a clear mandate to build a constitutional democracy predicated on ethnic diversity and value pluralism. ${ }^{30}$

Section 15(2) offers another clear example of state accommodation of comprehensive visions of the good within existing state structures. Section 15(2) reads: 'Religious observances may be conducted at state or state aided institutions provided that (a) those observances follow rules made by the appropriate public authorities; (b) they are conducted on an equitable basis; and (c) attendance at them is free and voluntary'. Assuming one religion represents all learners in a public school then the public school is well within its rights to hold religious observances. Assuming learners from several different religions attend a given public school then the public school may legitimately observe multiple religious rituals for its different constituencies. In either case, public space is being used to advance the ends of specific religious communities. ${ }^{31}$

The same must be said of the extent to which our constitutional order takes customary law and traditional leaders seriously. Traditional leaders have an entire chapter of the Constitution and a significant amount of legislation devoted to the exercise of their customary authority within a constitutional democracy. And here, it is not a matter of two systems operating in parallel or the traditional within the constitutional. ${ }^{32}$ Traditional leaders often exercise direct political authority over their constituents - and it is often the case that constituents turn to such leaders when municipal or provincial authorities fail to deliver services or resolve disputes. Traditional leaders exercise public power in public spaces.

30 S Woolman \& J Soweto-Aullo (note 21 above).

31 See P Farlam 'Freedom of Religion, Conscience, Thought \& Belief' in S Woolman et al (eds) Constitutional Law of South Africa 2ed (2003) chap 41; Currie \& De Waal (note 14 above) 336.

32 See TW Bennett \& C Murray 'Traditional Leaders' in S Woolman et al (eds) Constitutional Law of South Africa 2ed (2003) chap 26. 
The Constitution also places customary law on an equal footing with legislation, subordinate legislation, regulation and common law. Section 39(2) reads: 'When interpreting any legislation, and when developing the common law or customary law, every court, tribunal or forum must promote the spirit, purport and objects of the Bill of Rights.' Section 39(2) says nothing about two bodies of law - one public and one private. As the Pharmaceutical Manufacturers Court put it: 'There is only one system of law. It is shaped by the Constitution which is the supreme law, and all law, including the common law, derives its force from the Constitution and is subject to constitutional control. ${ }^{33}$ Indeed, the Constitutional Court has mediated conflicts between individual traditional interests and community traditional interests governed by both traditional bodies of law and statutory bodies of law as if there is but one system of law shared by multiple groups, associations and social formations. In Bhe, the Constitutional Court found that the customary law rule of male primogeniture - and several statutory provisions that reinforced the rule - impaired the dignity of and unfairly discriminated against the deceased's two female children because the rule and the other impugned provisions prevented the children from inheriting the deceased's estate. ${ }^{34}$ However, it is the manner in which the Bhe Court negotiates two different kinds of claims for equal respect from within the traditional community and from the perspective of western constitutional norms that is most instructive for our current purposes. The Bhe Court characterises the customary law of succession in terms that validate its spirit without necessitating that the Court be beholden to its letter. By having shown that: the spirit of succession lies in its commitment to family cohesion; that the traditional family no longer coheres as it once did; and that the 'distorted' rules of customary law are frozen in statute and case law that "emphasises ... patriarchal features and minimises its communitarian ones,'; the Bhe Court closes the gap between constitutional imperative and customary obligation. ${ }^{35}$ Had customary law been permitted to develop in an 'active and dynamic manner,' and not manipulated or perverted by apartheid, it would have already reflected the Bhe Court's conclusion that 'the exclusion of women from inheritance on the grounds of gender is a clear violation of ... [s] 9(3). ${ }^{36} \mathrm{Had}$ customary law not been allowed to ossify, traditional communities would have noted how male primogeniture entrenched 'past patterns of disadvantage among a vulnerable group' and endorsed the Bhe Court's re-working of customary understandings of the competence 'to own and

33 Ex parte President of the Republic of South Africa: In re Pharmaceutical Manufacturers Association of South Africa (2000) (2) SA 674 (CC) para 44.

34 Bhe $v$ Magistrate, Khayelitsha 2005 (1) SA 580 (CC).

35 Ibid para 89.

36 Ibid para 83. 
administer property' in a manner that vindicates a woman's right to dignity under s $10 .{ }^{37}$ The Bhe Court is able, therefore, to assert that traditional communities have conceptions of dignity worth protecting without being obliged to endorse a rule that quite clearly offends the dignity interests of many women and female children within those communities. ${ }^{38}$ And so, again, there are not two bodies of law - one public, one private. There is but one body of law: the basic, the constitutional.

This brief constitutional history of community rights, and especially the rights of religious, cultural and linguistic communities, captures the terrain upon which schools - public and private — based upon a particular comprehensive vision of the good life can operate. No iron wall exists between the public and the private, the sacred and the profane, in South African politics. Having said this, the Constitution's active encouragement of diversity and pluralism in the public realm does not diminish its equally aggressive commitment to the rooting out of discriminatory practices. As a result, the ability of communities to maintain institutions that rely upon exclusionary admissions or membership practices, while still receiving state support, is, as a constitutional matter, quite limited. The egalitarian commitments of our basic law also suggests that community-based institutions that rely upon exclusionary practices, but which do not receive a penny of state support, must likewise ensure that they do not offend constitutional and statutory norms designed to promote the dignity of all South Africans.

\section{The Legal Framework for Admissions and Language Policies at Public SchOOLS}

As we noted at the conclusion of the last section, the public space afforded for the advancement of sectarian interests, whether religious, linguistic or cultural, is quite limited. The importance of education as a public good in the modern nation state - for instrumental reasons associated with the future success of learners in the market or for intrinsic reasons that turn on every republic's need for citizens capable of making informed and just political decisions - means that the use of public school space for sectarian ends is even more tightly circumscribed. Thus,

37 Ibid para 84.

38 Hlophe J employs a similar disabling strategy in Mabuza v Mbatha 2003 (4) SA 218 (C). He recognises the supremacy of the Constitution at the same time as he asserts that the protean nature of customary law should enable it to conform, as necessary, to the dictates of the Bill of Rights. His nuanced assessment of the role of ukumekeza reconfigures siSwati marriage conventions in a manner that (a) refuses to allow ukumekeza to be used by the groom's family as a means of control over the bride and (b) consciously places the husband and wife on an equal footing with respect to subsequent determinations of whether a valid marriage under siSwati customary law has taken place. See S Woolman \& M Bishop 'Slavery, Servitude and Forced Labour' in S Woolman et al (eds) Constitutional Law of South Africa 2ed (2005) chap 64. 
while independent schools benefit from s 29(3)'s clear commitment to the creation of schools that further the ends of particular linguistic, cultural or religious communities - and permit exclusionary practices intended to further those ends - no public school is granted such autonomy. ${ }^{39}$

\section{(a) The 1996 Constitution}

In part II of this article, we noted that the Constitutional Court's (and other commentators') gloss on IC s 32(c) was quite generous. Recall that s 32(c) of the interim Constitution reads, in relevant part: 'educational institutions based on a common culture, language or religion' can be established, 'provided that there shall be no discrimination on the ground of race.' Kriegler J, writing for the Court in Gauteng School Education Bill, characterised these entitlements as follows:

[the Constitution keeps the door open for those for whom the State's educational institutions are considered inadequate as far as common culture, language or religion is concerned. They are at liberty harmoniously to preserve the heritage of their fathers for their children. But there is a price, namely that such a population group will have to dig into its own pocket. ${ }^{40}$

Again our liberal democratic constitution permits communities to establish institutions - such as schools - designed to further their preferred way of being in the world. However, there is no concomitant commitment made by the interim Constitution to state funding for such 'parochial' schools. As Matthew Chaskalson points out:

The placing of a positive obligation on the state to fund cultural and religious schools is not commonplace in comparative constitutional and public international law. Had this been the purpose of IC s 32(c), one might have expected it to have been expressed in unambiguous language. This is certainly what one finds in the few constitutions which do oblige the state to funds school based upon a common culture. Thus s 23 of the Canadian Constitution confers under subsection (1) a right on English and French speaking minority populations of any province to receive primary and secondary school instruction in their own language and then states categorically:

"(3) The rights of citizens of Canada under subsections (1) and (2) to have their children receive primary and secondary school instruction in the language of the English or the French minority population of a province ... (b) includes, where the number of those children so warrants, the right to have them receive that instruction in minority educational facilities provided out of public funds.

The absence in [IC] s 32(c) of any explicit provision for state funding of schools based upon a common language, religion, or culture therefore suggests that there is no constitutional obligation on the state to provide such funding. ${ }^{41}$

Chaskalson does note, however, that his findings are limited to the text of the interim Constitution and that no conclusions can be drawn from his analysis regarding s 32(c) and then be applied to the text of s 29 .

39 See S Woolman 'Defending Discrimination' (note 18 above).

40 Gauteng School Education Bill (note 26 above) para 42.

41 M Chaskalson 'Constitutional Issues Relevant to School Ownership, Governance and Finance' Durban Education Conference Papers (1995). 
Section 29 is both more and less expansive with respect to the latitude afforded parents of learners in both independent schools and private schools. Section 29(3) reads:

Everyone has the right to establish and maintain, at their own expense, independent educational institutions that (a) do not discriminate on the basis of race; (b) are registered with the state; and (c) maintain standards that are not inferior to standards at comparable public educational institutions.

Section 29(3) is on all fours, it would seem, with the gloss placed upon s 32(c) of the interim Constitution by Kriegler J in Gauteng Education Bill and by Matthew Chaskalson in his memorandum.

The real action, in so far as public schools are concerned, revolves around s 29(2). It is a complex provision:

Everyone has the right to receive education in the official language or languages of their choice in public educational institutions where that education is reasonably practicable. In order to ensure the effective access to, and implementation of, this right, the state must consider all reasonable educational alternatives, including single-medium institutions, taking into account: (a) equity; (b) practicability; and (c) the need to redress the results of past racially discriminatory laws and practices.

It is possible to identify two interpretive poles for this passage. At one end of the spectrum, some commentators contend that s 29(2) eliminates any express entitlement for single-medium public schools except where such schools offer redress for communities whose mother tongues were repressed under English and Afrikaner rule. At the other end of the spectrum, other commentators contend that s 29(2) vouchsafes continued state support for all single-medium public schools, and, in particular, single-medium Afrikaans schools. But s 29(2) does not support either of these two readings.

Let us begin with the uncompromisingly egalitarian position defended by Blade Nzimande. ${ }^{42}$ Nzimande construes s 29(2)'s second sentence requirements as matters of administration and policy, and not constitutional law. Though s 29(2)'s second sentence may provide a rather weak test for justification, it does not turn the choice of medium of instruction into a matter of mere policy preference. Moreover, s 29(2) does not, as Chaskalson suggested of s 32 of the interim Constitution, possess the structure of an affirmative action provision. Section 9(2) of the Constitution provides the perfect example of a constitutional norm whose aim is restitutionary justice. ${ }^{43}$ Whereas $s$ 9(2) differentiates between groups that have been historically disadvantaged and those that have not, s 29(2) does not do so. Single-medium public schools could be approved for any preferred language of instruction so long as instruction in a preferred language is reasonably practicable and the single-medium 
public school, as the best means of accommodating such instruction, satisfied the three threshold criteria of equity, practicability and redress. As we pointed out in part II, the Constitution, as a liberal political document, does not view all social, legal and economic arrangements through the prism of equality and reparations.

Commentators such as Rassie Malherbe, occupying the opposite end of the ideological and interpretative spectrum, contend that s 29(2) provides a strong guarantee — a rebuttable presumption — that linguistic communities can create and maintain publicly funded singlemedium schools. ${ }^{44}$ This misreading of the sub-section collapses the distinction between the individual right to instruction in a mother tongue or preferred language (where practicable) and the obligation imposed upon the state to consider a range of options as to how to offer such instruction. Malherbe privileges single-medium schools. ${ }^{45}$ Section $29(2)$ does not. It mentions single-medium public schools as only one in a range of alternatives that the state has an obligation to consider. Moreover, any option considered by the state for delivering mother-tongue instruction - one of which is single-medium schooling - must satisfy, to some degree, the three criteria of equity, practicablity and historical redress. Malherbe characterises the three s 29(2) criteria as mere factors to be considered in some global proportionality assessment. This characterisation of the three criteria seems far too weak. For a single-medium public school to be preferred to another reasonably practicable institutional arrangement — say dual-medium instruction or parallel-medium instruction - its advocates must demonstrate that a single-medium public school is more likely to advance or to satisfy the three criteria. Malherbe further claims that because the Constitution specifically refers to 'single-medium institutions' then 'whenever they [single-medium institutions] are found to be the most effective way to fulfill the right to education in one's preferred language, single-medium institutions should be the first option'. ${ }^{46}$ Once again, because Malherbe collapses the distinction between a right to mother-tongue instruction and a state duty to consider single-medium public schools, he fails to recognise that the right to the former - mother-tongue instruction — is subject to 'practicability', and that the derivative or secondary 'privilege' with respect to the latter - a single-medium public school — can only be a 'first option' for mother-tongue instruction if it meets the three threshold criteria of equity, practicality and redress. Finally, that Malherbe's interest in protecting single-medium public schools leads him to misread

44 See R Malherbe 'The Constitutional Framework for Pursuing Equal Opportunities in Education' (2004) 22 Perspectives in Education 9 ('Constitutional Framework'); R Malherbe 'A Fresh Start I: Education Rights in South Africa' 4 European Journal for Education Law \& Policy 49.

45 Malherbe 'Constitutional Framework' (note 44 above) 21.

46 Ibid 22. 
s 29(2) in its entirety is made patently clear from his final claim that the 'right to education in one's preferred language is guaranteed unequivocally in the South African Bill of Rights' ${ }^{47}$ This statement is clearly false. As the language of s 29(2) indicates, the right to receive education in the official language or languages of [one's] choice in public educational institutions' is subject to a powerful internal modifier - namely, the right exists only where the provision of 'that education is reasonably practicable'. ${ }^{48}$

Mahlerbe's analysis of s 29(2) brings to mind Jonathan Jansen's compelling portrait of Malherbe and other advocates of single-medium Afrikaans schools. Jansen writes:

[T]he problem with these kind of arguments is their lack of graciousness; and their singular lack of acknowledgement of history and politics in analyses that far too often betray an underlying logic of racial protection under the guise of minority rights. The fact that Afrikaans was one of only two official languages for at least half of the previous

47 Ibid.

48 For another reading of s 29(2) that falls somewhere between the Nzimande position and the Malherbe position, see G Bekker 'The Right to Education in the South African Constitution' Centre for Human Rights Occasional Papers, < http://www.chr.up.ac.za/centre_projects/socio/ compilation2part1.html > . Bekker writes: 'The Constitution does not guarantee mothertongue education for minorities, as does for example section 23 of the Canadian Charter of Rights and Freedoms. The Constitution, however, guarantees the right in public institutions to education in the language of one's choice. This is limited to education in an official language or languages and is further limited by the proviso - "where reasonably practicable". . . With regard to what would be "reasonably practicable", the Department of Education's Language in Education Policy provides that: it is reasonably practicable to provide education in a particular language of learning and teaching if at least 40 in Grades 1 to 6 or 35 in Grades 7 to 12 learners in a particular grade request it in a particular school... This is in keeping with the internationally practised sliding scale formula: the larger the number of speakers of a language in a particular area, the greater the obligation to provide mother-tongue education in that area. ... Furthermore, the Language in Education Policy provides that where there are fewer than the requisite number of learners that request to be taught in a particular language not already offered by a school in a particular school district, the head of the provincial department of education will determine how the needs of those learners will be met, taking into consideration the duty of the state and the right of the learners as spelled out in the Constitution. ... The second part of section 29(2) provides that the state has to ensure effective access to and implementation of the right to education. In this regard, the State must consider all reasonable alternatives including single-medium education, taking into account equity, practicability, and the need to redress the imbalances of the past. This would mean that where, for example, there are equal numbers of students seeking education in two different languages, a dual medium school might be the most equitable. Conversely, the most equitable solution might be a single-medium school in cases where the majority of students wish to be educated in one particular language. However, equitability is not the only deciding factor practicability will also have to be a taken into account. Here factors such as resources and numbers of teachers will play a role. Finally, the need to redress the imbalances of the past is emphasised. Thus, anything that will have the effect of denying or impeding the right to education of previously disadvantaged communities will also have to be taken into account'. (Emphasis added).

It is not clear why, on Bekker's account, a majority of learners ought to be able to determine that a single-medium school remains a single-medium school. That position is not consistent with the DoE's language policy, international practice or the text of s 29(2). A single-medium public school is simply one available means to ensure preferred language instruction: it is not a right possessed by all official language speakers. 
century - at the expense of other African languages; that Afrikaans might have been a language spoken by a demographic minority (white Afrikaans), but it was also the language of officialdom of a political majority (white South Africans); that Afrikaans still holds powerful negative memories of its role as the ideological vehicle for suppressing black nationalist aspirations that climaxed in the 1976 Soweto Student Uprising; and that Afrikaans still carries the heavy burden of white nationalist ambition within post-apartheid society. I have attended far too many parent meetings, university assemblies and quasipolitical gatherings of Afrikaners to be dissuaded that there are not powerful groups that seek to reestablish the link between white separatism and a race-exclusive ownership of the Afrikaans language; and the ideal place to continue harbouring such ambitions in a democratic state are schools and churches.... . There are negative consequences for students: their isolation in white Afrikaans-exclusive schools for twelve years seriously disables them from racial integration in the broader South African community. As a black Dean and academic leader at a former all-white, Afrikaans exclusive university, I witnessed daily the extreme difficulties young people from such schools encounter in an integrated higher education community. The only way in which to achieve Malherbe's 'balance' is to have schools with dual or, better still, multilingual practices in the same school grounds; you learn in and through the medium of Afrikaans, and you learn with and among children from diverse linguistic, cultural, religious and social backgrounds. This is the only way in which to both affirm Afrikaans as one of the eleven official languages and to break the underlying white nationalist ambition that undermines relationships between both Afrikaans-speakers and white Afrikaans-speaking students. ${ }^{49}$

Given this trenchant analysis, how should s 29(2) be parsed? We believe that it reads as follows.

1. Section 29(2) grants all learners 'the right to receive education in the official language or languages of their choice in public educational institutions where that education is reasonably practicable.' First note that the right to receive education in the official language or languages of one's choice is not, as the Supreme Court of Appeal in Mikro noted, an unqualified right. ${ }^{50}$ The right is subject to a standard of reasonable practicability. How should this internal limitation of the right be read? ${ }^{51}$ We suggest that where sufficient numbers of learners request instruction in a preferred language and, as we shall see below, we do possess regulations, as well as standards and norms, that make clear what those numbers are and no adequate alternative school exists to provide such instruction, then a public school is under an obligation - with assistance from the state - to provide instruction in the language of choice.

2. Before we proceed to the second sentence in s 29(2), it is worth taking another look at the meaning of 'reasonably practicable'. As

$49 \mathrm{~J}$ Jansen 'Race and Restitution in Education Law and Policy in South Africa and the United States' in C Russo, J Beckmann, and J Jansen (eds) Equal Education Opportunities: Comparative Perspectives in Educational Law (2006) 284-285.

50 Western Cape Minister of Education v The Governing Body of Mikro Primary School 2006 (1) SA 1 (SCA).

51 For more on how internal limitations clauses function in various substantive provisions in the Bill of Rights, see S Woolman \& H Botha 'Limitations' in S Woolman et al (eds) Constitutional Law of South Africa 2ed (2007) chap 34. 
an evidentiary matter, the learner or the learners or the state must be able to show that instruction in the language of choice is 'reasonably practicable' at the institution where the learners have applied for admission. So, for example, a single learner who requests instruction in Sepedi in a single-medium IsiZulu school may be hard pressed to demonstrate that it is reasonably practicable to accommodate her at a single-medium IsiZulu school. An inability to establish reasonable practicability would be even more pronounced where the learner who preferred instruction in Sepedi had access to an adequate school that offered Sepedi instruction. The failure to demonstrate that a request for instruction is 'reasonably practicable' ends the s 29(2) inquiry.

3. Assume, however, that the learner has shown that instruction in the language of choice is reasonably practicable at the institution where she has applied for admission. Only then do we consider the import of the second sentence of s 29(2). ${ }^{52}$

4. The second sentence of s 29(2) makes it patently clear that singlemedium institutions are but one way of accommodating the right of a learner to instruction in the language of choice. Moreover, the mere mention of single-medium schools in no way privileges such institutions over dual-medium schools, parallel-medium schools, or schools that accommodate the multilingualism of the student body in some other way. All that this portion of s 29(2) requires is that the state considers 'all reasonable educational alternatives' that would make mother tongue or preferred language instruction possible.

5. However, even if single-medium public schools are found to be one of the reasonable alternatives for preferred language instruction, the single-medium school must be able to satisfy a three factor test. That is, for a single-medium school to be preferred to another reasonably practicable institutional arrangement - say dual-medium instruction or parallel-medium instruction - it must demonstrate that it is more likely to advance or to satisfy the three listed criteria of equity, practicability and historical redress.

6. Section 29(2)'s concession to single-medium schools constitutes a very weak right indeed. (It is, perhaps, best described as a right to have reasons or an entitlement to justification.) That said, it is not without value for proponents of single-medium public schools. What the second sentence of s 29(2) ultimately requires is that the state be

52 It is worth drawing attention, here, to the basic structure of s 29(2). The first sentence bestows upon individual learners a right to instruction in a language of their choice. The second sentence sets out what the state's obligations are vis-à-vis the decision-making process for deciding whether schools ought to be single-medium, parallel medium, dual medium or something else entirely. Neither sentence in affords individual schools any rights with respect to determining the school's medium of instruction. 
able to justify its preference for one form of school over another. Given the Constitution's recognition of single-medium public schools as a legitimate means of providing preferred language education, the state will find itself under an obligation to demonstrate why another form of instruction - dual-medium, parallel-medium, special tutoring - will better serve the learners in question. Moreover, the Constitution's recognition of community rights, associational rights, religious rights, cultural rights and linguistic rights creates a set of background conditions against which claims for single-medium schools must be taken seriously. For where preferred language instruction is reasonably practicable, and where single-medium schools satisfy the desiderata of equity, practicability and historical redress, the state cannot simply invoke an overriding commitment to 'equality' or 'transformation' in order to dismantle single-medium institutions. The Constitution is, ultimately, a postapartheid constitution. Thus, at the same time as it sets its face against exclusion and discrimination, it rejects the kind of totalising view of the state that marked and marred apartheid. Space remains — within both the private realm and the public realm — for the accommodation of multiple ways of being in the world. That public space, as we have seen, is extremely narrow for single-medium public schools. ${ }^{53}$ But, however narrow it may be, it cannot be entirely wished away.

Where does this analysis leave us? Contrary to Malherbe and others, s 29(2) provides no right to single-medium public schools. At best, the sub-section recognises such schools as one option to be considered amongst a range of other institutional arrangements designed to further the instruction of learners. At best, it places an obligation on the state to justify any refusal to recognise and to support single-medium public schools. Advocates of single-medium Afrikaans public schools must recognise that when it comes to equity and historical redress, they are batting on a sticky wicket.

\section{(b) Statutory and regulatory framework}

The apposite legislation governing this area seem of a piece. They suggest that few exceptions to the egalitarian commitments of these documents

53 Under what circumstances would the state be justified in creating a separate single-medium public school rather than a parallel-medium school or a dual-medium school? Presumably, one could argue that a Khoi-San medium public school is necessary because of the historical disadvantage experienced by the Khoi-San people. Section 29(2) expressly recognises equity and historical redress as appropriate grounds for the creation of single-medium public schools — as well as parallel medium or dual medium schools. The irony, of course, is that s 29(2) arguments are being deployed by communities that, over the past 50 years at least, have been historically privileged. 
will be countenanced. The Schools Act rejects unfair discrimination on any grounds. The Promotion of Equality and Prevention of Unfair Discrimination Act 4 of 2000 (PEPUDA) and the regulations passed under the Gauteng School Education Act 6 of 1995 (GSEA) subject admissions requirements at public schools to even stricter scrutiny than the enabling legislation. ${ }^{54}$ While these regulations expand - in line with s 9 - the grounds for a finding of unfair discrimination with respect to admission policies, they do not make it absolutely impossible for a school governing body to run a public school with a particular comprehensive vision of the good life in mind. That said, s 29(2), when read with PEPUDA, the Schools Act, and GSEA, dramatically restricts the conditions under which single-medium public schools can claim the right to exclude learners who are 'non-speakers' of the single medium of instruction.

A raft of other statutory provisions, regulations and policies work to further restrict the space within which single-medium public institutions can operate. For example, s 5(3) of the Schools Act states that "no learner may be refused admission to a public school on the grounds that his or her parent ... (b) does not subscribe to the mission statement of the school.' One can't over-emphasise the importance of this provision. Some school governing bodies have, under existing law, arrogated to themselves sweeping powers of control over the governance and management of public schools. One mechanism of governance that such School Governing Bodies (SGBs) have employed in order to exclude unwanted learners is the school mission statement: such statements about a school's ethos cause many learners and their parents to self-select out of applying to given schools. This not-so-subtle form of exclusion occurs despite the fact that, according to s 5(3)(b) of the Schools Act, a mission statement which proclaims that the school environment and curriculum must advance the interests of the Zulu nation cannot be used to exclude learners who are not Zulu or committed to the furtherance of Zulu tradition, language and culture.

Another source of support for the argument that single-medium public schools, and their SGBs, cannot dictate school language policy in a manner that inhibits multilingualism can be found in the Norms and Standards for Language Policy in Public Schools promulgated in terms of the Schools Act and NEPA. These norms and standards place significant constraints on the ability of single-medium public schools to turn away learners who prefer, and will benefit from, instruction in another language. The Norms and Standards for Language Policy in Public

54 Regulations passed under the GSEA, s 11(1), and the Gauteng Education Policy Act 12 of 1998 ('GEPA'), s 4(a)(i), entitled 'Admission of Learners to Public Schools', General Notice 4138 of 2001 (PG 129 of 13 July 2001). 
Schools, promulgated in terms of s 6(1) of the Schools Act read, in relevant part:

C. The rights and duties of the school

(1) Subject to any law dealing with language in education and the Constitutional rights of learners, in determining the language policy of the school, the governing body must stipulate how the school will promote multilingualism through using more than one language of learning and teaching, and/or by offering additional languages as full-fledged subjects ... or through other means approved by the head of the provincial education department. (Emphasis added.)

(2) Where there are less than 40 requests in Grades 1 to 6 , or even less than 35 requests in Grades 7 to 12 for instruction in a language in a given grade not already offered in a particular school district, the head of the provincial department will determine how the needs of those learners will be met, taking into account: (a) the duty of the state and the rights of learners in terms of the Constitution; (b) the need to achieve equity; (c) the need to redress the results of past racially discriminatory laws and practices; (d) practicability; (e) the advice of the governing bodies and principals of the public schools concerned.

D. The rights and duties of the Provincial Education Departments

(3) It is reasonably practicable to provide education in a particular language of learning and teaching if at least 40 in Grades 1 to 6 or 35 in Grade 7 to 12 learners in a particular grade request it in a particular school. (4) The provincial head of department must explore ways and means of sharing scare human resources ... . and providing alternative language maintenance programmes in schools ... that cannot be provided with ... additional languages of teaching. ${ }^{55}$

These norms and standards contain a number of notable features. The norms make it clear that a group of 40 learners (grades 1 to 6) or a group of 35 learners (grades 7 to 12) constitute a sufficiently large cohort to demand instruction in a preferred language. A bar for linguistic accommodation has been set against which all schools may be measured. That said, these threshold requirements are not obligatory. They remain guidelines. What these norms tell us then is that the new South African state is not, unlike the apartheid state, a totalising entity. It will not subordinate the plural, comprehensive visions of the good life of its citizenry to an ideological commitment to equality. So while the state will apply pressure - through the law — on single-medium public schools to accept learners who prefer instruction in another language, it cannot use the mechanisms of a totalising state to achieve such ends. The somewhat ironic result of the norms and standards' commitment to linguistic pluralism and the status of the norms and standards as mere guidelines is that single-medium public schools - especially single-medium Afrikaans public schools — are 'encouraged' to maintain their current cramped sense of identity.

55 These policy statements were developed in terms of section 3(4)(m) of the National Education Policy Act 27 of 1996, and the Norms And Standards Regarding Language Policy Published In Terms Of Section 6(1) of the South African Schools Act, 1996 (Government Notice 383 of 9 May 1997). 


\section{(c) Case law}

Some may find the proposition that single-medium public schools are 'encouraged' to maintain their identity and retain their integrity hard to swallow. When viewed through the prism of single-medium public school advocacy, the statutes, the regulations and the policy circulars that articulate equity requirements at public schools and the body of case law built up over the past ten years may appear to evince nothing more than the state's desire to rid itself of single-medium Afrikaans-speaking public schools. ${ }^{56}$ And, in fact, the case law demonstrates that the primary fault line in public school admissions policy litigation occurs primarily around the use of Afrikaans as the sole medium of instruction.

Two features of this body of case law are worth noting at the outset. First, the courts have charted a course largely consistent with the analysis offered above - even if the cases themselves do not offer especially close readings of s 29(2) or other applicable laws. ${ }^{57}$ The five cases discussed below reflect the extent of the state's power in determining public school admissions requirements. They also reflect the sectarian interests that enjoy continued judicial solicitude - even in the face of the state's pursuit of increasingly egalitarian arrangements. Second, this quick survey of the cases litigated over language policy in public schools allows us to contrast, meaningfully, the space that various forms of community life - religion, language, culture - are afforded in the public realm with the space afforded various forms of community life in the private realm.

56 See 'Address by Naledi Pandor, MP, Minister of Education, Introducing The Debate on The Education Budget Vote 15, National Assembly' (17 May 2005), < http://www.pmg.org.za/ briefings/briefings.php?id =208 > : 'On Sunday I read reports in the press that English was to be made optional in schools. The report suggested that children will no longer learn English. That is not the intention of the policy. It opens up the possibility of developing the other official languages into languages of learning and teaching. Clearly while we work to achieve this noble objective, the current choice of English and Afrikaans as the languages of learning and teaching will remain. In the past, before 1998, pupils were locked into a system that privileged Afrikaans and English for those in search of a matric endorsement. That is now no longer true and all languages will now be equally available as subject choices'.

57 We would like to emphasise that the grounds for deciding these five cases does not generally 'fit' within the analytical rubric supplied by s 29(2) and the gloss we place on s 29(2). As most readers of South African case law and jurisprudence know, South African courts prefer technical textual solutions to resolutions that require that they answer vexed questions about the content of fundamental rights. See, especially, I Currie 'Judicious Avoidance' (1999) 15 SAJHR 138 (endorses the proposition that courts ought to avoid deciding the issues before them in terms of constitutional dictates.) See, further, C Sunstein One Case at a Time (1996). It seems reasonable to conclude, given this disposition of our courts, that our courts have avoided addressing the extent to which s 29(2) vouchsafes single-medium public schools because the matter is so politically charged. As we shall see, the Mikro court opts to resolve the dispute over single-medium public schools in terms of the Schools Act and the Laerskool Middleburg court ultimately turns to s 28(2) and the ostensibly unassailable proposition that the rights of the child are always paramount. However, all close and meaningful readings of legal texts go beyond the express language of a decision and concentrate their attention on the internal logic of a judgment or set of judgment. The internal logic of the five judgments speak pretty directly to the appropriate contours of s 29(2). 
It should come as no surprise that the Constitution and our courts refuse to endorse the arrangement of public institutions that distribute public goods in a manner that perpetuates the systemic discrimination, exclusion and oppression associated with apartheid. However, the Constitutional Court has made it patently clear that it recognises that the majority of South Africans draw the better part of the meaning in their lives from the religious, linguistic and cultural communities of which they are a part. Thus, while the state may be entitled to set limits on the extent to which state resources can be used to advance sectarian ends, the Constitution vouchsafes significant amounts of private space within which various comprehensive visions of the good life can be pursued.

\section{(i) Matukane $e^{58}$}

As one might have predicted, the state has weighed in on the side of black students who wish to receive instruction in English, but found themselves excluded from Afrikaans medium, or predominantly Afrikaans medium, public schools. At issue in Matukane v Laerskool Potgietersrus was the attempt by the parent of three learners, Mr Matukane, to enroll his three children (13, 13 and 8) at the Laerskool Potgietersrus. The Laerskool Potgietersrus was then, and remains still, a state-aided parallel-medium primary school.

Mr Matukane, a black resident of Potgietersrus, spoke to the principal on 11 January 1996. The principal informed $\mathrm{Mr}$ Matukane that $\mathrm{Mr}$ Matukane would have to wait until 25 January 1996 for a determination as whether there was space available at the school. Mr Matukane was not convinced that any such delay was warranted. He approached the provincial Department of Education ('DoE'). DoE informed $\mathrm{Mr}$ Matukane that his children could be enrolled in the school. $\mathrm{Mr}$ Matukane arrived at the school on 22 January 1996, completed the necessary application forms and bought the school uniforms as directed. The application form included a section requiring that parents and children agree to adhere to the rules and the objectives of the school. The stated objective on the application form read: 'the provision of excellent and relevant education with a Christian national character in mothertongue medium Afrikaans or English.' Mr Matukane returned the next day with his children for their first day at school. The entrance of the school was blocked by a group of white parents who refused to allow $\mathrm{Mr}$ Matukane or his children to enter the school. Mr Matukane returned to the school again the following day. A standoff between a group of black parents and students and white parents and students ensued. Once again the Matukane children were denied access to the school. After being 
rebuffed this second time, Mr Matukane managed to secure a temporary place for his children at the already overcrowded Akasia School, the only other English medium school in the town.

Other black parents had experienced less dramatic rejections by the school. They were told that their children could not be accommodated because the school was full. At least 55 black children had been refused admission to the school in this manner. No black child had ever been admitted to the school. No black children appeared on the current waiting list. On top of these indignities, the school bussed in white children from Zebediela, a neighboring town - despite the fact that a school catering to Afrikaans-speaking students in Zebediela had space available. After Mr Matukane's experience of overt racial discrimination, a group of black parents decided to approach the High Court for an order requiring the Laerskool Potgietersrus to accept their children.

In the High Court, Laerskool Potgietersrus argued that it was unable to accommodate more children and that it had not rejected the children on racial grounds. At the time of the hearing, Laerskool Potgietersrus had 580 Afrikaans-speaking students and 89 English-speaking students. The Laerskool Potgietersrus expressed concern that if it admitted these children, it would be swamped by English-speaking children who would destroy the Afrikaans ethos of the school. The school contended that s 32(c) of the Interim Constitution protected the right 'to establish, where practicable, educational institutions based on a common culture, language or religion, provided that there shall be no discrimination on the ground of race' and entitled the school to adopt admissions requirements designed to maintain the existing 'culture' and 'ethos' of the school. The Laerskool Potgietersrus also asserted that a DoE directive gave the school governing body the sole power to determine its criteria for admission.

Despite the school's assertion that the refusals were based on overcrowding, not race, the facts clearly painted a different picture. No black children had been admitted to the school. There were no black children on the waiting list. White English-speaking learners had already been admitted. Afrikaans-speaking students were being bussed in. Room existed to accommodate more English-speaking children. Little danger existed of the school's Afrikaans culture and ethos being destroyed even if every black English-speaking learner were to be accepted. The ratio of Afrikaans-speaking students to English-speaking students would remain 5:1. Given these facts, the court held that it could draw no other inference as to actual intent of the school's admissions policy than that it discriminated directly on the basis of race, ethnic and social origin, culture and language. Given that the discrimination took place on one or more of IC s 8's listed grounds, unfairness was presumed. The burden shifted to the school to show that the discrimination was fair.

As Gauteng Education Bill clearly holds, the respondents had the right, 
under IC s 32(c), to establish an independent educational institution designed to promote Afrikaans language and culture so long as they did not discriminate on the basis of race. The school had no right to exclude learners from a public institution based upon culture, and it certainly had no right to exclude any learner based upon race. (Moreover, while the Laerskool Potgietersrus might have been justified in its desire to privilege Afrikaans over English, the school failed to demonstrate why a modest increase in black English-speaking students would deleteriously effect the school's promotion of Afrikaans language and culture.) The court concluded that 'language and culture' were operating as surrogates for 'race', that the school had discriminated intentionally against the Matukane children and other black learners on the grounds of race and that the respondent could not, therefore, discharge its burden of proving the fairness of its (racist) admissions policies.

\section{(ii) Laerskool Middelburg ${ }^{59}$}

Laerskool Middelburg en ' $n$ ander $v$ Departementshoof, Mpumalanga Departement van Onderwys, en andere extends the holding in Matukane from parallel-medium to single-medium schools. However, in Laerskool Middelburg, the High Court was clearly more troubled by the apparent conflict between the alleged right to a single-medium school and the uncontroversial right to be educated in the official language of one's choice.

At the level of rhetoric, the Laerskool Middelburg court initially rebuffed the provincial Department of Education's attempt to turn the single-medium school into a parallel-medium school. It held that neither the Schools Act, nor the regulations issued under them, authorised the provincial Head of the Department to instruct a school to change from single-medium instruction to parallel-medium instruction and declared that the Head's administrative conduct was prima facie unfair. ${ }^{60}$ The Laerskool Middelburg court then rejected the Department's argument that the applicant school's admission policy discriminated unfairly against English learners. The High Court held that in circumstances in which the English learners could be accommodated elsewhere, the Department's actions simultaneously violated the s 29(2)-based entitlement right of Afrikaans-speaking students to single-medium schools and the s 29(2) right of English-speaking students to an education in the official language of their choice in public educational institutions. ${ }^{61}$

Having notified the state that it had failed to take cognisance of s 29's commitment to linguistic diversity, the court conceded that any

59 Laerskool Middelburg v Departementshoof, Mpumalanga Departement van Onderwys 2003 (4) SA $160(\mathrm{~T})$.

60 Ibid $171-172$ and 176.

61 Ibid 173 and 175. 
entitlement to a single-medium school was subordinate to the right of every South African to a basic education, the right to be educated in a language of choice and the palpable need of all South Africans to share education facilities with other linguistic and cultural communities. The court was unwilling to allow the needs of 40 English-speaking - and largely black - learners to be prejudiced by the state's failure to play by the rules and by the school's intransigence on the issue of parallelmedium education. Section 28(2)'s guarantee that 'the best interests of the child' are always of 'paramount importance' was held by the court to trump the language and cultural rights of the school's Afrikaans learners. ${ }^{62}$ So while the state's actions had, in fact, been mala fide, it was still able to secure a victory for educational equity by getting the proper parties - namely the children - before the court.

Although the outcome was certainly correct, the court's route in arriving at its conclusion cannot pass without comment. If our reading of s 29(2) offered above is accurate, then the court should never had had to rely on s 28(2). In terms of s 29(2), the court should have first determined whether it was 'reasonably practicable' to accommodate English-speaking students in Laerskool Middelburg. The court's conclusion - that the only public school in the area had to take in 20 local learners - suggests that it was 'reasonably practicable'. That should, or could, have been enough. But further support for the court's conclusion can be found in the second sentence of s 29(2): 'In order to ensure the effective access to, and implementation of, this right, the state must consider all reasonable educational alternatives, including single-medium institutions, taking into account: a. equity; b. practicability; and c. the need to redress the results of past racially discriminatory laws and practices.' The court's conclusion that a single-medium school must, in order to accommodate these 20 learners, become a parallel-medium school is consistent with a reading of $s$ 29(2) that makes it patently clear that single-medium

62 In deciding that the 'minority' students must be accommodated, the Laerskool Middelburg court correctly concluded that the right to a single-medium public educational institution was clearly subordinate to the right which every South African had to education in a similar institution and to a clearly proven need to share education facilities with other cultural communities. The Laerskool Middelburg court seems to be on far shakier grounds when it suggested that it was an open question as to whether the exercise of one's own language and culture was better furthered in a single-medium environment. The court's claim that a singlemedium institution was probably best defined as a claim to emotional, cultural, religious and social-psychological security trivialises the desire to maintain basic, constitutive attachments. The desire to sustain a given culture - especially a minority culture, as Afrikaner culture now is - is best served by single-medium institutions that reinforce implicitly and expressly the importance of sustaining the integrity of that community. As a result, the Laerskool Middelburg court must also be wrong when it claims that the conversion of a single-medium public institution to a dual-medium school cannot per se diminish the force of each ethnic, cultural and linguistic community's claim to a school organised around its language and culture. Ibid at 173 . That is, with respect, exactly what the conversion per se does. 
institutions are but one way of accommodating the right of a learner to instruction in the language of choice and that the mere mention of singlemedium schools in no way privileges such institutions over parallel medium schools or dual medium schools. The second sentence of s 29(2) - and its commitment to equity, practicability and historical redress provides further justification for the Laerskool Middelburg court's conclusion that a single-medium institution was obliged, under the circumstances, to become a parallel-medium institution.

\section{(iii) $M I K R O^{63}$}

At issue in Western Cape Minister of Education v Governing Body of Mikro Primary School was the refusal of an Afrikaans medium public school to accede to a request by the Western Cape Department of Education ('WCDoE') to change the language policy of the school so as to convert it into a parallel-medium school. Acting on behalf of 21 learners, the WCDoE had directed the primary school to offer instruction in their preferred medium: English. The WCDoE had interpreted the Norms and Standards issued by the National Department of Education under the Schools Act as requiring all primary schools with 40 learners who preferred a particular language of learning and teaching to offer instruction in that language.

The Supreme Court of Appeal summarily rejected both the WCDoE's reading of the Norms and Standards and its gloss on s 29(2). It did so on three primary grounds.

First, the Supreme Court of Appeal overturned Bertelsmann J's finding in Laerskool Middelburg that the Norms and Standards provided a mechanism for the alteration of the language policy of a public school. At best, the Supreme Court of Appeal said, the Norms and Standards constituted guidelines for members of the department and those parties responsible for the governance of public schools. Second, the Supreme Court of Appeal held that the Schools Act's s 6(1) granted neither the national Minister of Education nor the provincial MEC or Head of Department the authority to determine the 'language policy of a particular school, nor does it authorise him or her to authorise any other person or body to do so.' The power to determine language policy vests solely with the SGB of a given public school and is subject only to the Constitution, the Schools Act and any applicable provincial law. Third, the Supreme Court of Appeal rejected the applicant's contention that s 29(2) could be 'interpreted to mean that everyone had the right to receive education in the official language of his or her choice at each and every public educational institution where this was reasonably practic- 
able. ${ }^{64}$ Such a reading, the Mikro Court held, would mean that any significant cohort of learners could demand instruction in their preferred language if it was conceivably possible to do so. The Mikro Court noted that such a gloss on s 29 would lead to the absurd consequence that 'a group of Afrikaans learners would be entitled to claim [a right] to be taught in Afrikaans at an English medium school immediately adjacent to an Afrikaans medium school which has vacant capacity provided they can prove that it would be reasonably practicable to provide education in Afrikaans at that school. ${ }^{65}$ The Supreme Court of Appeal held that the correct reading of s 29(2) affords the state significant latitude in deciding how best to implement this right and that s 29(2) grants everyone a right to be educated in an official language of his or her choice at a public educational institution if, in the totality of circumstances, it is reasonably practicable to do so. That means, of course, that the right is only to language instruction, generally, and, thus to instruction at some school within an accessible geographical domain, and not, as the applicants had claimed, to language instruction at each and every public educational institution and thus to any school the applicants wished to attend.

The decision is notable in two important respects. First, it curbs the state's power to determine - exclusively — public school admissions and language policies. Such power continues to be shared - to some degree - with each existing SGB. Second, while affirming the rights of learners to instruction in a preferred language, it simultaneously confirmed that some individual schools were entitled to offer instruction in a single medium.

The effect of the Supreme Court of Appeal's decision in Mikro is to reverse, partially, the spin of Laerskool Middelburg. Neither parallelmedium instruction nor dual-medium instruction are automatic default positions for public school language policy. The Mikro Court takes the language of s 29(2) seriously. It places the state under an obligation to show that its language policy — designed to give learners instruction in their preferred language - is reasonably practicable. Thus, where, as in Mikro, it is not reasonably practicable to give English speaking students instruction at a single-medium Afrikaans speaking institution, because other adequate alternatives exist, then the state cannot force a singlemedium Afrikaans speaking institution to offer parallel instruction. Although the Mikro Court does not engage the second sentence of s 29(2), one can easily draw the inference that the state would have failed to discharge the burden of showing that it had considered all reasonable alternatives for accommodating the English speaking learners in question and that it had also failed to demonstrate that maintaining a singlemedium Afrikaans-speaking school - in circumstances where adequate 
English medium instruction was available elsewhere - offended the constitutional commitment to equity and to historical redress. It is impossible to read Mikro and not come away with the impression that a community's interest in maintaining its linguistic and cultural integrity may - under a narrow set of conditions - legitimately trump purely ideological considerations of equity.

\section{(iv) Seodin $^{66}$}

Seodin reinforces the holdings in Matukane and in Laerskool Middelburg and appears to confirm the impression that Mikro only protects singlemedium public schools under a relatively narrow set of circumstances. In Seodin Primary School v MEC Education, Northern Cape, the High Court held that the SGBs of three Afrikaans medium public schools could not use language preference alone to exclude black, English speaking learners from admittance where the provision of English language instruction was 'reasonably practicable'. In addition, in all three cases heard in Seodin, the single-medium Afrikaans schools were undersubscribed. Finally, the High Court found that public pronouncements by the MEC for Education on the need for greater integration in the public schools system could not be interpreted as an ultra vires act aimed at the elimination of single-medium — read Afrikaans — public schools. Where public schools are concerned, Seodin makes it clear that the Constitution will not tolerate racist and discriminatory admissions policies masquerading as policies that claim to be about the need to maintain the language and the culture of a given community. As Northern Cape Judge President Kgomo noted in his judgment:

It would be a sad day in the South African historical annals that hundreds of children remained illiterate or dropped out of school because they were excluded from underutilised schools purportedly to protect and preserve the status of certain schools as singlemedium Afrikaans schools. ${ }^{67}$

\section{(v) Hoërskool Ermelo ${ }^{68}$}

Hoërskool Ermelo offers perhaps the best set of circumstances under which to assess - in terms of s 29(2) - the respective rights of learners to choose their preferred language of instruction, the ability of SGBs to determine public school language policy, and the power of the state to alter language policy where the needs of learners so warrant.

In Hoërskool Ermelo I, Prinsloo J, of the Pretoria High Court, suspended a decision of the Mpumalanga education department to

66 Seodin Primary School v MEC Education, Northern Cape 2006 (1) All SA 154 (NC).

67 Ibid para 56.

68 Hoërskool Ermelo v Departmentshoof van die Mpumalanga Case Number 3062/07, Unreported Decision of Pretoria High Court, 2 February 2007. 
dissolve the school's governing body and to replace it with a departmentally appointed committee. The dissolution would have enabled the Mpumalanga education department to alter the school's language policy and allowed 113 English-speaking pupils to receive instruction in English. ${ }^{69}$

On appeal, a full bench set aside the High Court ruling in Hoërskool Ermelo I. The Hoërskool Ermelo II court found that the Afrikaansmedium school must admit English-speaking pupils. Of particular moment for the Hoërskool Ermelo II court was the under-subscription of the school. Given that the Hoërskool Ermelo was operating at only half-capacity, the full bench found that it was 'reasonably practicable' as contemplated by s 29(2) — for the high school to accommodate the 113 eight grade learners. The mere fact that all classrooms were being employed and that the existing curriculum turned on the current availability of classrooms did not constitute sufficient grounds for excluding English learners and maintaining Hoërskool Ermelo as a single-medium Afrikaans public school. Equity, practicability and historical redress - the three express grounds for assessment of existing language policy in terms of $s$ 29(2) - justified the transformation of Hoërskool Ermelo from a single-medium public school into a parallelmedium public school.

\section{CONCLUSION}

The foregoing account supports a number of relatively uncontroversial conclusions. The Constitution - and a broad array of statutes recognise that for religious, cultural and linguistic communities to survive and to flourish in South Africa, these communities must be able to establish educational institutions that cater for their specific 'ethos'. Such institutions must, by there very nature, enforce admissions policies that discriminate between learners who wish to participate in affairs of a given religious, linguistic and cultural community, and those learners who do not wish to participate in or advance the ways of being of a given community. The Constitution, PEPUDA, the Schools Act, NEPA and a raft of regulations certainly allow independent schools or private schools to employ admissions policies that discriminate between learners in a

69 Prinsloo J's interim order froze Mpumalanga education MEC Siphosezwe Masango's instruction that Ermelo High School enrol 113 children that the provincial government claimed could not be placed in the other schools in the area. Prinsloo $\mathbf{J}$ ruled that his interim order should stand until a full hearing on the matter was held. The Department of Education decided not to wait for the full hearing. In their papers, the DoE and the parents of the learners claimed that right to education in the language of choice was impaired by the school's language policy and its refusal to admit children who were not prepared to be taught in Afrikaans. In addition, the Mpumalanga DoE claimed that its position was underwritten by the under-subscription at Ermelo and the oversubscription at adjacent high schools. 
manner carefully designed to advance legitimate constitutional ends. ${ }^{70}$ However, when it comes to public schools, the state's tolerance for discrimination of any kind - even via means narrowly tailored to realise otherwise legitimate constitutional objectives — ought to be tightly circumscribed and rightly inclines in favour of learners from historically disadvantaged communities. As we have seen in our analysis of s 29(2), where sufficient resources exist to ensure that all South African learners receive an adequate, and for all intents equal, education in their preferred language of instruction, then the state ought to do everything it can to accommodate linguistic and cultural diversity and should operate in a manner that enables single-medium schools to continue to exist. However, the Constitution's commitment to meaningful transformation means that the right of all learners to a basic education in their preferred language of instruction at public schools generally trumps more particularistic claims on public resources. The Constitution's answer to those parents who wish to school their children in the language, culture or religion of their choice is straightforward: you may 'dig into your own pocket' and build an 'independent school' on your own time.

Thus, when we ask whether a public school that wishes to provide an education in Afrikaans for Afrikaans children can employ an admissions policy that discriminates between applicants on the basis of their willingness to adhere to a curriculum that requires that all classes be taken in Afrikaans, the answer must be 'that depends'. The Constitution, the Schools Act, PEPUDA and cases such as Matukane, Laerskool Middelburg, Seodin and Ermelo all buttress the proposition that discrimination on the basis of language or culture cannot be used as a proxy for discrimination on the basis of race. A proper analysis of s 29(2) reinforces the proposition - at least implicitly accepted by the Matukane, Laerskool Middelburg, Mikro, Ermelo and Seodin courts that where learners do not have ready access to a public school that offers them adequate instruction in their preferred medium of instruction, then

70 See S Woolman 'Defending Discrimination' (note 18 above). See also Taylor v Kurtstag [2004] 4 All SA 317 (W) (s 18 of the Constitution — freedom of association — 'guarantees an individual the right to choose his or her associates and a group of individuals the right to choose their associates.' The right of a group to choose their associates of necessity means the right to require those who wish to join the group to conform their behaviour to certain dictates, and the right to exclude those who refuse to conform); Wittmann $v$ Deutsche Schülverein, Pretoria 1998 (4) SA 423 (T), 451 ('Does this mean that private parochial schools which do not receive State aid may not prescribe obligatory attendance at their morning prayers and confessional religious instruction classes? The answer is negative. Section 17 of the interim Constitution and s 18 of the [1996] Constitution recognise the freedom of association. Section 14(1) [interim Constitution] and s 15(1) [of the 1996 Constitution] respectively recognise the freedom of religion which includes the right to join others in worship, propagation of the faith etc. Freedom of association entails the right with others to exclude non-conformists. It also includes the right to require those who join the association to conform with its principles and rules.') 
neither a School Governing Body nor a principal can exclude learners in terms of an admissions policy that seeks to privilege a particular language. The lesson of the Supreme Court of Appeal's decision in Mikro is that the window for exclusion on the basis of language and culture is rather small indeed: only where the learners in question already have easy access to a school that offers them adequate instruction in their preferred medium of instruction, can the single-medium school in question claim, with some force, that neither the learners nor the state has any business forcing a single-medium institution into becoming a parallel-medium institution. $^{71}$

Let us be clear. The Constitution neither provides a guaranteed right to single-medium public schools nor does it prohibit the existence of such institutions. The Constitution sets its face against the kind of cultural and linguistic hegemony that marked apartheid and, at the same time, recognises the necessity of a multiplicity of patterns of school language policy. The principle constitutional norms that bracket language policy do not entail some ideological pre-commitment to any particular language practice: for example English over Afrikaans, or Zulu over Xhosa. Instead these norms require that any language policy meet such fixed, yet fluid, desiderata as equity, practicability and historical redress. In some instances, this set of constitutional desiderata will allow for the continued existence of single-medium Afrikaans public institutions. In other instances, circumstances will dictate that such schools change their language policy. In either case, the state must be in a position to offer a compelling evidentiary basis for its conclusion regarding the change or the maintenance of a single-medium schools' language policy. In the absence of such reasons, our courts will view state-sponsored changes in policy as arbitrary exercises of state authority and violations of the apposite constitutional and statutory provisions.

For many, the constitutional obligation placed on the state to justify its actions may not provide sufficient solace. For those learners and their

71 The willful misconstruction of the constitutional space that exists for single-medium schools is evident from the following press release:

The Federation of Afrikaans Cultural Associations, the FAK, welcomes the Supreme Court of Appeal's rejection of an appeal by the Western Cape MEC for Education to try and force Laerskool Mikro to change its language policy. This judgment is a victory for the autonomy of communities and in fact represents a small step closer to the application of the National Department's policy of mother-tongue instruction for all South African children. The FAK hopes that the continuing pressure by provincial education departments on Afrikaans schools to anglicise in the name of greater access will cease. Currently several Afrikaans schools countrywide are subject to such pressure, with possible court action involved. The FAK appeals to provincial education departments to stop playing off the right to access against mother-tongue instruction, and to alleviate the crisis of access to quality education for all by applying themselves to make mother-tongue instruction a reality for all South African children.

Federation of Afrikaans Cultural Associations 'FAK welcomes the Mikro Judgment' (June 27, 2005), < http://vryeafrikaan.co.za/lees.php?id $=272>$. 
parents for whom the window provided by s 29(2) is too small and for whom a single-medium school designed to further a particular linguistic, cultural or religious vision of the world is an absolute necessity, the Constitution again has an answer. Under s 29(3), they may 'dig into their own pocket' and build the school on their own time and in their own fashion. $^{72}$ 